\title{
The Impact of Microsponge and Microsphere on Improving Oral Bioavailability of Medications: A Short Review
}

\author{
Yasir Alshehry, ${ }^{1, *}$ and Mohammed Jafar ${ }^{l}$
}

Department of Pharmaceutics, College of Clinical Pharmacy, Imam Abdulrahman Bin Faisal University, Dammam 34212, Saudi Arabia

\section{ARTICLE INFO}

Received 03 December 2021

Revised 26 January 2022

Available Online 15 February 2022

\section{ACADEMIC EDITOR}

Dr. M.A. Jahangir

\section{*CORRESPONDING AUTHOR}

Yasir Alshehry, Department of Pharmaceutics, College of Clinical Pharmacy, Imam Abdulrahman Bin Faisal University, Dammam 34212, Saudi Arabia

\begin{abstract}
While many diseases require an efficient drug delivery technology that has the ability to improve bioavailability and alleviate side effects, various types of gastroretentive drug delivery systems (GRDDS) have been developed in order to overcome the obstacles, which are related to a narrow absorption window, instability, site of action, side effects, and dosing frequency. In this context, microsponge and microsphere systems depict two different types of GRDDS, aiming to provide adequate time for active ingredients to be absorbed in the stomach despite the variation in releasing mechanisms of the entrapped ingredients. For the successful designing of these systems, it is essential to optimize the characterizations of the formulated microparticles by considering physiological, pharmaceutical, and patientrelated factors, which have a dramatic impact on the efficacy. Consequently, they will demonstrate different behaviors at the desired site of action, determining which systems are showing superiority compared to others. However, each microparticle system has some advantages over the others, providing more options for researchers to ease the difficulties that exist with conventional oral dosage forms. Therefore, this review aims to shed the light on critical factors that have significant impacts on microsponge and microsphere systems and addresses their advantages and disadvantages, providing an understanding of these criteria in order to optimize the drug systems.
\end{abstract}

Keywords: Microsponge; Microsphere; Bioavailability; Oral drug; Gastro retentive drug delivery system

\section{Introduction}

The majority of healthcare systems across many countries are grappling with exponentially increasing expenses. In part, such price hikes can be explained by medication cost despite the existence of a competitive market among pharmaceutical companies. Globally, the cost of prescribed medications in 2020 was estimated to be $\sim 1.3$ trillion dollars of which the United States was expected to spend around $\$ 350$ billion [1]. In addition, governmental organizations also take part in shaping the market pricing by the type of regulations and restrictions they implement in their own health care system or pharmaceutical industries [2,3].

To address this issue and reduce the burden on patients' budgets, the need for a new technology is required. In this era, the evolution in the drug delivery technology has increased dramatically because there is still a need for an effective medication with fewer side effects. For instance, typically, gastric diseases required a medication that has the ability to stay for a long period in the upper gastrointestinal tract (GIT). One of the 
solutions suggested to solve this issue is a system called gastroretentive drug delivery system (GRDDS) [4]. This system uses different types of carriers, which also includes microsponge, to deliver an active ingredient to a predetermined area. In addition, this system improves the bioavailability of poorly absorbed medication and controls the drug release in order to increase patient compliance [5]. Similarly, another study conducted by Romly et al. which included 123,243 patients of which $55 \%$ took extended-release medications and the remaining were on conventional tablets, revealed that the adherence to the treatment increased significantly among those on the extended-release regimen in comparison with the conventional group [6]. Likewise, these findings were consistent with a meta-analysis reported by Wang et al. which involved 13,452 patients [7].

Furthermore, GRDD System is designed to overcome some obstacles related to conventional oral dosage forms (e.g., tablets, capsules, syrup, suspensions, or powders), such as frequent drug intake per day and high cost of the treatment, depending on the type of diseases and severity. On the other hand, in order to avoid these obstacles that exist with the conventional tablets, the preparation methods are considered a cornerstone in manufacturing the GRDDS. To illustrate, many factors in this system play significant roles to achieve the required efficiency. For example, the ratio of drug to polymer directly impacts the particle size, whereas the temperature has negligible effect under certain circumstances [8]. Moreover, Ibrahim and Gawhri demonstrated that internal phase volume, stirring speed, and stirring duration had also direct or indirect effects on microsponge [9]. Garg and Gupta revealed similar results for the microsphere system. Therefore, Gastroretentive drug delivery systems (GRDDS), including both microsponge and microsphere, are promising technologies for medications with narrow absorption windows compared to conventional tablets if they are prepared under particular circumstances, which will significantly improve drug release profile and physicochemical characteristics, as well [10].

\section{Critical Factors Affecting Microsponge and Microsphere Efficacy}

Microsponge and microsphere are two different types of GRDDS aiming to provide adequate time for the active ingredients to be absorbed in the stomach despite that both of them are made by different chemicals, and they release the entrapped medication by a different mechanism of action. In addition, even though various technologies that consider part of GRDDS are reported previously by many authors, both microsponge and microsphere technologies are the most widespread gastroretentive formulations in pharmaceutical companies. Historically, in 1987, Won addressed for the first time the microsponge technology, while the original patent was designated to Advanced Polymer Systems, Inc. At that period, this technology was mainly used for topical formulations; however, the researchers are trying to use this technology to treat some gastric diseases by delivering the needed medication through the GIT. In general, the microsponge system is defined as small spherical particles, ranging between $5 \mu \mathrm{m}$ up to $300 \mu \mathrm{m}$, with a porous surface that allowed active ingredients to release in a controlled rate for a specific period of time [11]. On the other hand, microsphere was defined by Sah et al. as "microscopic spherical objects with diameters ranging from ten millimeters to a thousand millimeters" [12].

For the successful design of the two systems, there are mainly three important factors that impact the efficacy by various ways, which are categorized into physiological, pharmaceutical, and patient-related factors. In terms of pharmaceutics, it is vital to understand the basic concepts of excipients and polymers in order to formulate an effective dose. In the mucoadhesive system, for instance, hydroxypropyl methylcellulose (HPMC) and carbopol have excellent mucoadhesion strength that will add adhesive features to the formula. Other considerable factors that need certain attention are polymer's characteristics, such as viscosity, physicochemical properties, and molecular weight. Furthermore, shape and size could play a major role in this technology. For instance, Streubel et al. demonstrated that, in order to prolong the gastric residence time of the dosage form in the stomach, the particle should have a ring or tetrahedron shape [13]. In most cases, the gastric residence time of GRDDS proportionally relies on the size of the particle. To illustrate, as the particle size of the dosage form increase, it will be difficult to pass through the pyloric antrum, located in the intestine, due to the particle's size exceeding the diameter size $(12.8 \pm 7 \mathrm{~mm})$ of pyloric sphincter [14]. Similarly, in the low-density system such as microsponge and microsphere systems, it is mandatory to ensure that the system has a density less than the gastric fluid density, which has been reported as $1.004 \mathrm{~g} / \mathrm{cm}^{3}$ [15]. Consequentially, the systems will have the ability to remain floating on gastric fluid. Although decreasing the density will enhance the ability to float for a long time in the gastric, the presence of the 
Citation: Alshehry Y, Jafar M. The Impact of Microsponge and Microsphere on Improving Oral Bioavailability of Medications: A Short Review. J Pharm Res Sci Technol 2022; 6(1): 155. doi: 10.31531/jprst.1000155

food in the stomach will lead to reduce gastric residence time.

There is substantial evidence that several physiological factors including but not limited to the physical activity, posture, food intake, sleep, ingestion frequency, and nature of calories have different influences on the residence time of micro sponge and sphere in the gastric area [16]. For example, if the caloric density increase, the gastric residence time will increase as well whereas the nature of calories has an insignificant impact on the residence time [17]. In terms of food intake, a randomized cross-over study conducted by Zhu et al. included fifteen healthy males of which received standard and high viscous semi-solid meals in two different sessions [18]. As result, when participants received the high viscosity meal, the gastric residence time increased. Thus, the medication will remain floating in the stomach for a longer time if it is given with high viscosity meal.

Another major category that influences the performance of the GRDDS is patient-related factors. Age, gender, emotional state, and illness can interfere with both the micro sponge and sphere systems. A recent study included 215 healthy volunteers revealed that females had longer gastric residence time than males due to the effect of hormones, while the gastric acid secretion was reported higher in males than females $[19,20]$. Likewise, the age of the patients influences the gastric residence time. A randomized study included 12 males and 12 children, conducted by Mojaverian et al. showed that gastric residence time was prolonged in the elderly participants compared to the youngers, especially in subjects above 70 years old [21]. Furthermore, it has been demonstrated by many authors that some type of disease affects the gastric residence time or gastric empty rate. For example, Parkinson's patients usually have low gastric motility which leads to prolong gastric residence time, and in some cases, they will end up constipation eventually [22]. Similarly, the gastric emptying time decreases by 30 to 50 percent in diabetic patients [23]. Therefore, those patients should receive low dose with less frequency in order to avoid toxicity. For emotional state, it was observed that the residence time was increased in depressed patients, while it decreases in patients experiencing anxiety [24].

The microsponge can be utilized as a novel approach for sustaining the drug release, improving the bioavailability and therapeutic effects and, at meanwhile, alleviating the untoward effects of several drugs. In oral administration, these benefits of microsponges could be achieved through $\mathrm{pH}$ changes, for drugs that are released at a particular site of GIT, and delaying of gastric retention time, mainly for drugs which have their absorption window in the stomach or in the upper part of the small intestine [25]. The gastric floating microsponge of curcumin developed using the two polymers eudragit and ethylcellulose together by Arya et al. demonstrated a drug release of 88.4 to $90.8 \%$ of curcumin after 8 hours of the release study [26]. In another study reported by Singh et al., the cumulative drug release values obtained for the loratadine gastric floating microsponge prepared using ethylcellulose alone were comparatively slightly lower numbers 66.75 to $88.15 \%$ drug release [27] and in one more study, it is reported that cinnarizine release from the gastric floating microsponge was far less and it was between 57.9 and $88.7 \%$ at the end of same 8 hours [28]. However, on increasing the duration of the in vitro drug release study from 8 to 12 hours and with the use of both the polymers eudragit and ethylcellulose together in the microsponge preparation it was noticed that the drug release was almost complete as reported by Chargonda et al. [29]. Analyzing the determination coefficient, Higuchi model was the best model kinetic mechanism to describe the drug release from floating microsponges consisting of polymers eudragit, ethylcellulose, and organic solvents ethanol, and dichloromethane [26]. Zero-order release was the best fit kinetic model for the microsponges developed with anyone polymer ethylcellulose or eudragit and dichloromethane alone as a solvent [29]. It is thus clear that the variation in the drugs release from the floating microsponges of curcumin [26], cinnarizine [28], famotidine [29], and loratadine [27] are related to the polymeric and solvent composition of each type of gastric floating microsponges. As far as the release mechanisms are concerned, all floating microsponges exhibited drug release governed by Fickian diffusion mechanisms [26,27], except to lower concentration of eudragit and it was governed by diffusion and swelling mechanisms [27]. Moreover, the general trend reported for the size of the above microsponges was that on increasing the drug to polymer ratio and also on increasing the emulgent concentration in the microsponge the size of the microsponges was increased and which in turn delays the lag and log time of floating of the microsponges. In Table-1 the brief summary of studies reported on gastric floating microsponge on different drugs is presented. 
Citation: Alshehry Y, Jafar M. The Impact of Microsponge and Microsphere on Improving Oral Bioavailability of Medications: A Short Review. J Pharm Res Sci Technol 2022; 6(1): 155. doi: $\underline{10.31531 / j p r s t .1000155}$

\section{Advantage and Disadvantage of Microsponge and Microsphere Systems}

Microsponge and microsphere systems shared similar advantages over other conventional dosage forms. It is evident that the systems improve the absorption of narrow window medications, such as lisinopril, ranitidine, captopril, NSAIDs and some antibiotics etc., and enhance overall the bioavailability. This improvement achieves by reducing the particle size of the medications and prolong the gastric residence time as a result of making the systems float on the gastric fluid. In addition, these two systems can work as site specific systems to target and treat some gastric diseases. Theoretically, ulcer, gastric cancer, and Helicobacter pylori infection could be treated efficiently by microsponge or microsphere systems since both of them deliver and remain in the gastric area for a long time. Another benefit of the systems over the conventional forms is reducing the dosing frequency per day. For instance, some type of NSAID medications or antibiotics describes for the patient as two to four times per day. If the micro sponge or sphere use to replace the conventional pills, the patient will take the medication once per day instead of four times [30].

However, the microsponge, by itself, has some superior features over the microsphere system. One type of the microsphere system called microcapsule cannot control the drug release similar to the microsponge systems because it has a layer covering the active ingredient from the outside, and once that layer ruptures for any reason, the whole amount of the active ingredient will release at the same time. Likewise, the microsponge has better $\mathrm{pH}$ stability, ranging from 1 to 1 , and it can remain intact in high temperature up to $130^{\circ} \mathrm{C}$. In addition, the microsponge has self-sterilizing characteristics due to average pour size in $0.25 \mu \mathrm{m}$, where bacteria cannot penetrate into the particle. On the other hand, the microsphere system has the ability to protect sensitive active ingredients from enzymes. Also, this system considers a preferable option for light sensitive medication because the out layer that covers the system prevents the light from penetrating into the particle [12,31].

Table 1: Recent studies on gastric floating microsponge system.

\begin{tabular}{|c|c|c|c|c|c|c|c|}
\hline Drug & Polymers & $\begin{array}{l}\text { Method of } \\
\text { preparation }\end{array}$ & $\begin{array}{l}\text { Entrapment } \\
\text { efficiency \% }\end{array}$ & $\begin{array}{c}\text { Buoyancy } \\
\%\end{array}$ & $\begin{array}{c}\text { Drug } \\
\text { release } \\
\%\end{array}$ & Key Findings & Reference \\
\hline Allopurinol & $\begin{array}{c}\text { Ethyl } \\
\text { cellulose; } \\
\text { Eudragit EPO }\end{array}$ & $\begin{array}{c}\text { Quasi } \\
\text { emulsion } \\
\text { solvent } \\
\text { diffusion }\end{array}$ & 90.61 & 86.52 & 94.23 & $\begin{array}{l}\text { High entrapment } \\
\text { efficiency; } \\
\text { Sustained drug } \\
\text { delivery }\end{array}$ & [32] \\
\hline \multirow[b]{2}{*}{ Baclofen } & $\begin{array}{c}\text { Eudragit RS } \\
100\end{array}$ & $\begin{array}{l}\text { Non-aqueous } \\
\text { emulsion } \\
\text { solvent } \\
\text { diffusion } \\
\end{array}$ & 81 & - & 75 & $\begin{array}{l}\text { Controlled drug } \\
\text { release }\end{array}$ & [33] \\
\hline & $\begin{array}{c}\text { Eudragit RS } \\
100\end{array}$ & $\begin{array}{l}\text { Oil-in-oil } \\
\text { emulsion } \\
\text { solvent } \\
\text { diffusion }\end{array}$ & 81 & 88.11 & 75 & $\begin{array}{l}\text { Controlled drug } \\
\text { release }\end{array}$ & {$[34]$} \\
\hline Bupropion & Ethyl cellulose & $\begin{array}{c}\text { Quasi } \\
\text { emulsion } \\
\text { solvent } \\
\text { diffusion }\end{array}$ & 73 & - & 88.6 & $\begin{array}{l}\text { High entrapment } \\
\text { efficiency } \\
\text { Controlled drug } \\
\text { release } \\
\end{array}$ & [35] \\
\hline Cinnarizine & $\begin{array}{l}\text { Polyvinyl } \\
\text { alcohol }\end{array}$ & $\begin{array}{l}\text { Quasi } \\
\text { emulsion } \\
\text { solvent } \\
\text { diffusion }\end{array}$ & 82.4 & 82.3 & 88.7 & $\begin{array}{l}\text { Sustained drug } \\
\text { release; } \\
\text { High entrapment } \\
\text { efficiency; } \\
\text { Bioadhesive }\end{array}$ & [28] \\
\hline
\end{tabular}


Citation: Alshehry Y, Jafar M. The Impact of Microsponge and Microsphere on Improving Oral Bioavailability of Medications: A Short Review. J Pharm Res Sci Technol 2022; 6(1): 155. doi: $\underline{10.31531 / j p r s t .1000155}$

\begin{tabular}{|c|c|c|c|c|c|c|c|}
\hline Curcumin & $\begin{array}{c}\text { Ethyl } \\
\text { cellulose; } \\
\text { Eudragit }\end{array}$ & $\begin{array}{l}\text { Quasi } \\
\text { emulsion } \\
\text { solvent } \\
\text { diffusion }\end{array}$ & 82 & 90.7 & 85.2 & $\begin{array}{c}\text { Oral } \\
\text { bioavailability of } \\
\text { curcumin } \\
\text { enhanced } \\
\end{array}$ & [26] \\
\hline Famotidine & Eudragit s 100 & $\begin{array}{c}\text { Quasi } \\
\text { emulsion } \\
\text { solvent } \\
\text { diffusion } \\
\end{array}$ & 88.3 & 76.4 & 86.9 & $\begin{array}{l}\text { High entrapment } \\
\text { efficiency } \\
\text { Sustained drug } \\
\text { release } \\
\end{array}$ & [29] \\
\hline loratadine & $\begin{array}{c}\text { Ethyl } \\
\text { cellulose; } \\
\text { AccononMC8 } \\
\text { 2EP/NF } \\
\end{array}$ & $\begin{array}{l}\text { Emulsion- } \\
\text { solvent } \\
\text { diffusion }\end{array}$ & 65.98 & - & 88.15 & $\begin{array}{l}\text { Controlled drug } \\
\text { release; } \\
\text { Bioadhesive }\end{array}$ & [27] \\
\hline Piroxicam & $\begin{array}{c}\text { Eudragit } \\
\text { RS100, RL100 } \\
\text { and S100 }\end{array}$ & $\begin{array}{l}\text { Quasi- } \\
\text { emulsion } \\
\text { solvent } \\
\text { diffusion }\end{array}$ & 98 & - & $\begin{array}{c}\text { Almost } \\
100\end{array}$ & $\begin{array}{l}\text { Enhanced drug } \\
\text { solubility and } \\
\text { dissolution rate }\end{array}$ & [36] \\
\hline $\begin{array}{l}\text { Mitiglinide } \\
\text { Calcium }\end{array}$ & $\begin{array}{l}\text { Ethyl } \\
\text { cellulose; } \\
\text { Eudragit } \\
\text { RS100 }\end{array}$ & $\begin{array}{l}\text { Quasi- } \\
\text { emulsion } \\
\text { solvent } \\
\text { diffusion }\end{array}$ & 77.7 & 91.01 & 83.74 & $\begin{array}{c}\text { Improved oral } \\
\text { bioavailability; } \\
\text { Controlled drug } \\
\text { release }\end{array}$ & [37] \\
\hline Sulpride & $\begin{array}{l}\text { Eudragit } \\
\text { RS100; } \\
\text { Polyvinyl } \\
\text { alcohol }\end{array}$ & $\begin{array}{l}\text { Quasi- } \\
\text { emulsion } \\
\text { solvent } \\
\text { diffusion }\end{array}$ & 77.07 & 89.31 & 88.37 & $\begin{array}{c}\text { Increased oral } \\
\text { bioavailability; } \\
\text { Controlled drug } \\
\text { release }\end{array}$ & [38] \\
\hline Ranitidine & $\begin{array}{c}\text { Eudragit } \\
\text { RS100 }\end{array}$ & $\begin{array}{l}\text { Double } \\
\text { emulsion }\end{array}$ & 68.2 & $>75.00$ & 71.9 & $\begin{array}{c}\text { Improved antiulcer } \\
\text { activity }\end{array}$ & [39] \\
\hline Luteolin & $\begin{array}{c}\text { Eudragit RS } \\
100 ; \\
\text { Ethyl cellulose }\end{array}$ & $\begin{array}{l}\text { Quasi- } \\
\text { emulsion } \\
\text { solvent } \\
\text { diffusion }\end{array}$ & 67.33 & - & 50.22 & $\begin{array}{c}\text { Improved anti } H . \\
\text { pylori activity }\end{array}$ & [40] \\
\hline
\end{tabular}

\section{Conclusion}

In conclusion, Gastroretentive drug delivery system (GRDDS), including both microsponge and microsphere systems, has superior features over conventional dosage forms due to enhancing the bioavailability and improving the stability and the absorption of narrow window medications. Also, prolonging the gastric residence time of medications in the stomach due to the floating ability of the systems, which lead to reduce the dosing frequency, has a great impact on increasing patient compliance. These advantages cannot be achieved without considering pharmaceutical factors and physiological and patientrelated variables. In addition, these factors and variables play a critical role to create an efficient system that able to overcome the obstacles of conventional systems. However, although both microsponge and microsphere systems serve the same goals, each system has its own advantages over the others, and it is quite difficult to consider which one is better than the other without existing head-to-head comparative study. Therefore, the need for such a study is required in order to fill that gap.

\section{Consent for Publication}

Not applicable.

\section{Funding}

None.

\section{Conflict of Interest}

The author declares no conflict of interest, financial or otherwise.

\section{Acknowledgements}

We gratefully thank Dr. Natalya Watson (Northeastern University, Boston) for providing her useful comments and suggestions. 
Citation: Alshehry Y, Jafar M. The Impact of Microsponge and Microsphere on Improving Oral Bioavailability of Medications: A Short Review. J Pharm Res Sci Technol 2022; 6(1): 155. doi: 10.31531/jprst.1000155

\section{References}

1. IQVIA. (2019, January). The global use of medicine in 2019 and outlook to 2023. https://www.iqvia.com/insights/the-iqviainstitute/reports/the-global-use-of-medicine-in2019-and-outlook-to-2023.

2. Levit LA, Balogh E, Nass SJ, Ganz P, editors. Delivering high-quality cancer care: charting a new course for a system in crisis. Washington, DC: National Academies Press; 2013 Dec 27.

3. Tang N, Eisenberg JM, Meyer GS. The roles of government in improving health care quality and safety. The Joint Commission Journal on Quality and Safety. 2004 Jan 1;30(1):47-55.

4. Jahangir MA, Kazmi I, Muheem A, Ahmad K. Development and Evaluation of a Novel OroSustained Stomach Specific Floating in Situ Gelling System of Azithromycin Dihydrate. Int $\mathbf{J}$ PharmTech Res. 2014 Oct;6:1774-82.

5. Jahangir MA, Saleem MA, Shahab MS, Muheem A, Saleem S. Formulation and Evaluation of Novel Floating In Situ Gelling System of Macrolide Antibiotic Using Different Gelling Polymers. Journal of Drug Delivery and Therapeutics. 2015 Sep 21;5(5):48-55.

6. Romley JA, Xie Z, Chiou T, Goldman D, Peters AL. Extended-Release Formulation and Medication Adherence. Journal of general internal medicine. $2020 \mathrm{Jan} ; 35(1): 354-6$.

7. Wang L, Sun X, Du L, Yuan Q, Li H, Tian H, Li Y. Effects and patient compliance of sustained-release versus immediate-release glipizides in patients with type 2 diabetes mellitus: a systematic review and meta-analysis. Journal of evidence-based medicine. 2011 Nov;4(4):232-41.

8. Resmi DS, Mathew P, Dev AP, Abraham E. Formulation and evaluation of topical econazole nitrate microsponge loaded hydrogel. Indian Journal of Pharmacy and Pharmaceutical Research. Human. 2018;12(1):27-64.

9. Ibraheem FQ, Gawhri FJ. Preparation and In-vitro Evaluation of Baclofen as an Oral Microsponge Tablets. Iraqi Journal of Pharmaceutical Sciences. 2019;28(1).

10. Garg R, Gupta GD. Gastroretentive floating microspheres of silymarin: preparation and in vitro evaluation. Tropical journal of pharmaceutical research. 2010;9(1).

11. Kappor D, Patel M, Vyas RB, Lad C, Tyagi BL. A review on microsponge drug delivery system. Journal of Drug Delivery and Therapeutics. 2014 Sep 14;4(5):29-35.
12. Sah SK, Vasia M, Yadav RP, Patel S, Sharma M. Microsphere Overview. Asian Journal of Pharmaceutical Research and Development. 2021 Aug 14;9(4):132-40.

13. Streubel A, Siepmann J, Bodmeier R. Gastroretentive drug delivery systems. Expert opinion on drug delivery. 2006 Mar 1;3(2):217-33.

14. Salessiotis N. Measurement of the diameter of the pylorus in man: Part I. Experimental project for clinical application. The American Journal of Surgery. 1972 Sep 1;124(3):331-3.

15. Chauhan MS, Kumar A, Pathak K. Osmotically regulated floating asymmetric membrane capsule for controlled site-specific delivery of ranitidine hydrochloride: optimization by central composite design. AAPS PharmSciTech. 2012 Dec;13(4):1492-501.

16. Hooda A, Nanda A, Jain M, Kumar V, Rathee P. Optimization and evaluation of gastroretentive ranitidine $\mathrm{HCl}$ microspheres by using design expert software. International journal of biological macromolecules. 2012 Dec 1;51(5):691-700.

17. Calbet JA, MacLean DA. Role of caloric content on gastric emptying in humans. The Journal of physiology. 1997 Jan 15;498(2):553-9.

18. Zhu Y, Hsu WH, Hollis JH. The impact of food viscosity on eating rate, subjective appetite, glycemic response and gastric emptying rate. PLoS One. 2013 Jun 20;8(6):e67482.

19. Wang YT, Mohammed SD, Farmer AD, Wang D, Zarate N, Hobson AR, Hellström PM, Semler JR, Kuo B, Rao SS, Hasler WL. Regional gastrointestinal transit and $\mathrm{pH}$ studied in 215 healthy volunteers using the wireless motility capsule: influence of age, gender, study country and testing protocol. Alimentary pharmacology \& therapeutics. 2015 Sep;42(6):761-72.

20. Feldman M, Barnett C. Fasting gastric $\mathrm{pH}$ and its relationship to true hypochlorhydria in humans. Digestive diseases and sciences. 1991 Jul 1;36(7):866-9.

21. Mojaverian P, Vlasses PH, Kellner PE, Rocci ML. Effects of gender, posture, and age on gastric residence time of an indigestible solid: pharmaceutical considerations. Pharmaceutical research. 1988 Oct;5(10):639-44.

22. Krygowska-Wajs A, Cheshire Jr WP, Wszolek ZK, Hubalewska-Dydejczyk A, Jasinska-Myga B, Farrer MJ, Moskala M, Sowa-Staszczak A. Evaluation of gastric emptying in familial and sporadic Parkinson disease. Parkinsonism \& related disorders. 2009 Nov 5;15(9):692-6. 
Citation: Alshehry Y, Jafar M. The Impact of Microsponge and Microsphere on Improving Oral Bioavailability of Medications: A Short Review. J Pharm Res Sci Technol 2022; 6(1): 155. doi: $\underline{10.31531 / j p r s t .1000155}$

23. Triantafyllou K, Kalantzis C, Papadopoulos AA, Apostolopoulos P, Rokkas T, Kalantzis N, Ladas SD. Video-capsule endoscopy gastric and small bowel transit time and completeness of the examination in patients with diabetes mellitus. Digestive and Liver Disease. 2007 Jun 1;39(6):57580.

24. Shaha SH, Patel JK, Pundarikakshudu K, Patel NV. An overview of a gastro-retentive floating drug delivery system. Asian journal of pharmaceutical sciences. 2009 Jan;4(1):65-80.

25. Barrocas PM, Santos DF, Ferreira DC, Coelho PM, Oliveira RC, Veiga FJ. Pharmaceutical gastroretentive systems. Revista Brasileira de Ciências Farmacêuticas. 2007;43:325-34.

26. Arya P, Pathak K. Assessing the viability of microsponges as gastro retentive drug delivery system of curcumin: optimization and pharmacokinetics. International journal of pharmaceutics. 2014 Jan 2;460(1-2):1-2.

27. Singh S, Pathak K. Assessing the bioadhesivity of Acconon MC 8-2 EP/NF for gastroretention of floating microsponges of loratadine and achieving controlled drug delivery. Pharmaceutical and Biomedical Research. 2016 Jun 10;2(2):58-74.

28. Raghuvanshi S, Pathak K. Bioadhesive floating microsponges of cinnarizine as novel gastroretentive delivery: Capmul GMO bioadhesive coating versus acconon MC 8-2 EP/NF with intrinsic bioadhesive property. International journal of pharmaceutical investigation. 2016 Oct;6(4):181.

29. Charagonda S, Puligilla RD, Ananthula MB, Bakshi V. Formulation and evaluation of famotidine floating microsponges. International research journal of pharmacy. 2016;7(4):62-7.

30. Sandipan NH, Raosaheb SS, Vishal HV. Review On Gastroretentive Drug Delivery System. Indo American Journal of Pharmaceutical Sciences. 2018 Mar 1;5(3):1439-47.

31. Chandra U, Dhyani A, Juyal D. Review on floating microsponges: An updated. The Pharma Innovation. 2017 Jul 1;6(7, Part D):239.
32. Patel D, Gohil D, Patel D, et al. Formulation and evaluation of floating microsponges of allopurinol. Pharm Sci Monit. 2016; 7(3),135-154.

33. Ibraheem FQ, Gawhri FJ. Preparation and In-vitro Evaluation of Baclofen as an Oral Microsponge Tablets. Iraqi Journal of Pharmaceutical Sciences. 2019;28(1).

34. Ibraheem, F.Q. and Abdelrazzaq, A.A., (2019). Studying the effect of variables on baclofen floating microsponge. International Journal of Research in Pharmaceutical Sciences, 10(3), pp.2300-2306.

35. Muralidhar P, Bhargav E, Srinath B. Formulation and optimization of bupropion hel microsponges by $2^{\wedge}$ sub $3^{\wedge}$ factorial design. International Journal of Pharmaceutical Sciences and Research. 2017 Mar $1 ; 8(3): 1134$.

36. Rajab NA, Jawad MS. Formulation and in vitro evaluation of piroxicam microsponge as a tablet. Int J Pharm Pharm Sci. 2016;8(2):104-4.

37. Mahmoud DB, Shukr MH, ElMeshad AN. Gastroretentive microsponge as a promising tool for prolonging the release of mitiglinide calcium in type-2 diabetes mellitus: optimization and pharmacokinetics study. AAPS PharmSciTech. 2018 Aug;19(6):2519-32.

38. Younis MA, El-Zahry MR, Tallat MA, Tawfeek HM. Sulpiride gastro-retentive floating microsponges; analytical study, in vitro optimization and in vivo characterization. Journal of drug targeting. 2020 Apr 20;28(4):386-97.

39. Jafar M, Mohsin AA, Khalid MS, Alshahrani AM, Alkhateeb FS, Alqarni AS. Ranitidine hydrochloride stomach specific bouyant microsponge: Preparation, in-vitro characterization, and in-vivo anti-ulcer activity. Journal of Drug Delivery Science and Technology. 2020 Feb 1;55:101453.

40. Jafar M, Salahuddin M, Khan MS, Alshehry Y, Alrwaili NR, Alzahrani YA, Imam SS, Alshehri S. Preparation and In Vitro-In Vivo Evaluation of Luteolin Loaded Gastroretentive Microsponge for the Eradication of Helicobacter pylori Infections. Pharmaceutics. 2021 Dec;13(12):2094.

Copyright: (92022 Alshehry and Jafar. This article is distributed under the terms of the Creative Commons Attribution 4.0 International License (http://creativecommons.org/licenses/by/4.0/), which permits unrestricted use, distribution, and reproduction in any medium, provided you give appropriate credit to the original author(s) and the source, provide a link to the Creative Commons license, and indicate if changes were made. 